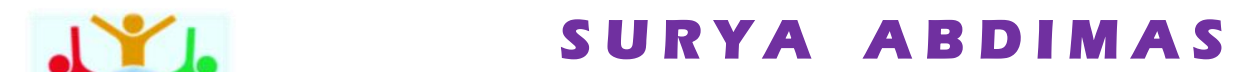

Vol. 5 No. 3 (2021) pp. 338 - 346

Available online at: http://jurnal.umpwr.ac.id/index.php/abdimas/index

p-ISSN: 2580-3492 e-ISSN: $\underline{2581-0162}$

\title{
Pendampingan Anak Didik Agar Tetap Ceria dan Sehat di Era Transisi New Normal
}

\section{Elida Florentina Sinaga Simanjorang $\varangle$, Lolita Restiana Siahaan, Hasian Risdouli Hutagaol, Betabenaria Limbong}

\section{Universitas Labuhanbatu}

Jl. SM. Raja No. 126A KM. 3,5 Aek Tapa, Rantauprapat, Kab. Labuhanbatu, Sumatera Utara, Indonesia | buelida.dosenku@gmail.com $\bigotimes$ | DOI : https://doi.org/10.37729/abdimas.v5i3.1245 |

\begin{abstract}
Abstrak
PAUD/TK Amalianur desa Pematang Seleng adalah salah satu satuan pendidikan yang melaksanakan sistem belajar dari rumah selama masa pandemi Covid-19. Seiring dengan dinamika yang terjadi, dalam beberapa bulan terakhir sistem belajar sudah diselingi dengan 1-2 kali pertemuan tatap di sekolah setiap minggunya. Dari hasil diskusi dengan guru-guru dan pengamatan terhadap anak didik PAUD/TK Amalianur, ditemukan permasalahan yaitu meningkatnya kejenuhan belajar anak didik akibat sistem belajar dari rumah. Anak didik mengeluhkan merasa bosan dengan rutinitas mengerjakan tugas di rumah, kesendirian, dan merindukan teman-teman untuk bermain yang mana keceriaan serta bermain merupakan kebutuhan anak seusia mereka. Tujuan dari pengabdian ini adalah memberikan dukungan kesehatan mental kepada anak didik melalui kegiatan belajar sambil bermain, bernyanyi, mewarnai, berdoa, dan ceramah pengetahuan terkait Prokes dan prakteknya. Metode yang digunakan adalah ceramah dan praktek langsung. Kegiatan pengabdian ini dilakukan mengikuti 3 alur pelaksanaan kegiatan yaitu Tahap Persiapan, Tahap Pelaksanaan, dan Tahap Evaluasi. Implikasi dari pelaksanaan pengabdian kepada masyarakat ini adalah terciptanya keceriaan dalam belajar dan bermain, mengurangi kejenuhan yang dialami anak didik akibat monton belajar dari rumah, selain menambah wawasan pengetahuan bagaimana sikap hidup sehat (Prokes) selama masa transisi new normal, serta tetap membangun spritual keimanan anak didik melalui hapalan doa-doa singkat Islami.
\end{abstract}

Kata Kunci: Pendampingan, Anak didik, New Normal

cc) (i) (8) This work is licensed under a Creative Commons Attribution-NonCommercial 4.0 International License

\section{Pendahuluan}

Desa Pematang Seleng merupakan salah satu desa di kecamatan Bilah Hulu, kabupaten Labuhanbatu, Sumatera Utara, yang terdiri dari 10 dusun yaitu Pekan, Kampung Lalang, Sri II, Gunung Sari, Makmur, Griya, Sidodadi, Tapian Nauli, Janji Matogu, dan Perumnas N-8. Letak desa yang dapat di katakan cukup strategis yakni merupakan jalan lintas Sumatera sehingga menjadi desa yang cukup berkembang dan relatif padat penduduknya. Penduduk desa Pematang Seleng sebagian besar beragama Islam, kemudian disusul Kristen, Budha dan Hindu. Pada beberapa dusun telah berdiri beberapa bangunan masjid dan gereja untuk tempat ibadah bagi warga. Sebagian besar penduduk desa Pematang Seleng ini bekerja sebagai petani karet dan sawit, serta sebagiannya lagi bekerja di perkebunan yang berada di sekitar desa. Di desa ini juga telah berdiri beberapa sekolah, salah satunya adalah PAUD/TK Amalianur yang berada di dusun Sidodadi. 
PAUD/TK Amalianur ini terdiri dari 1 kelas PAUD dan 2 kelas TK. Jumlah peserta didik adalah 70 siswa dengan dewan guru sejumlah 6 orang. Sebagaimana satuan pendidikan lainnya, dimana selama masa pandemi Covid-19 ini sekolah pada umumnya melakukan pembelajaran dari rumah dan daring (Latifah, 2020; Sama, Bahri, \& Budiyono, 2020), maka PAUD/TK Amalianur ini juga menyelenggarakan sistem belajar dari rumah. Dalam beberapa bulan terakhir ini, sistem belajar sudah diselingi dengan 1-2 kali pertemuan tatap muka di sekolah setiap minggunya.

Data Satuan Tugas Penanganan Covid-19 (Satgas Covid) pusat menunjukkan bahwa 47 persen anak Indonesia yang melakukan kegiatan belajar dari rumah di masa pandemi ini merasakan kebosanan (Agustina dkk., 2019; Ningsih, 2020). Tanda-tanda tekanan mental dan emosional akibat pandemi ini juga dialami pada anak-anak di sejumlah negara di seluruh dunia. Dosen Departemen Ilmu Keluarga dan Konsumen, Fakultas Ekologi Manusia (IKK-Fema) Institut Pertanian Bogor (IPB), Eva Riany menyebutkan, kebijakan sistem belajar dari rumah telah menimbulkan polemik bagi seluruh anak didik dan orang tua siswa meskipun dengan derajat yang bervariasi (Yulianingsih dkk., 2020). Menurut Kompas (Arifa, 2020) sejak 16 Maret sampai 9 April 2020, Komisi Perlindungan Anak Indonesia (KPAI) menerima sekitar 213 pengaduan terkait sistem belajar dari rumah baik dari orang tua maupun anak didik. Data yang diperoleh dari survei penilaian cepat yang dilakukan oleh Satgas Covid-19 menunjukkan bahwa 47 persen anak Indonesia merasa bosan di rumah, 35 persen anak merasa khawatir ketinggalan pelajaran, 15 persen anak merasa tidak aman, 20 persen anak merindukan teman-temannya dan 10 persen anak merasa khawatir tentang kondisi ekonomi keluarga. Kondisi ini apabila tidak diatasi, akan menyebabkan hal yang lebih fatal.

Salah satu masalah yang terjadi pada sistem belajar dari rumah yaitu kejenuhan belajar atau bisa disebut juga dengan burnout belajar. Menurut Sutjipto (Robiatul Adawiyah, 2013) "Burnout merupakan wujud dari perubahan kondisi psikologis berupa kelelahan fisik (physical exhaustion), kelelahan emosional (emotional exhaustion) dan kelelahan mental (mental exhaustion)". Artinya kejenuhan yang dialami oleh siswa bisa berasal dari perubahan kondisi psikologis. Menurut (Agustina et al., 2019) menambahkan bahwa "kejenuhan (burnout) belajar berasal dari rutinitas yang monoton, seperti tugas yang terlalu banyak, kurangnya kontrol diri, tekanan yang tinggi, tidak dihargai, aturan yang sulit dipahami, tuntutan yang saling bertentangan, diacuhkan, kehilangan kesempatan, dan deadline tugas". Artinya kejenuhan yang dialami anak didik berasal dari hal yang monoton dan harus diubah agar anak didik tidak mengalami kejenuhan. Untuk itu, diperlukan upaya strategis dalam memberikan dukungan kesehatan mental bagi anak didik. Belajar sambil bermain, serta dukungan spritual berupa hapalan doa adalah salah satu cara memberikan dukungan kesehatan mental bagi anak didik selama pandemi dan transisi new normal. Atas dasar pemikiran tersebut maka dirasakan perlu diberikan pendampingan kepada anak didik untuk sejenak menciptakan suasana belajar yang ceria, tidak monoton, menambah wawasan baru tentang kesehatan selain pelajaran sekolah, mengasah daya kreatifitas, serta tidak ketinggalan tetap dalam koridor membangun spritualitas keimanan anak didik.

RA Kartini, sang pemikir visioner, sejak ratusan tahun lalu melalui tulisannya sudah meyakinkan kita bahwa pendidikan di sekolah tidaklah mungkin cukup dilakukan oleh pihak sekolah. Kemitraan sekolah dan masyarakat yang dinamis sangat dibutuhkan dalam mendukung pendidikan anak di sekolah (Maujud, 2017; Samsiah, dkk., 2018). Sesungguhnya masyarakat dan sekolah saling berkaitan dan dapat saling topang, sehingga keberhasilan pendidikan bukan saja menjadi tanggung jawab sekolah 
saja, tetapi juga merupakan tanggung jawab masyarakat dan tentu saja tanggung jawab pemerintah. Masyarakat harus terjun langsung ke tengah-tengah dunia pendidikan turut berpartisipasi dalam memajukan anak didik, begitu juga pemerintah memberikan dorongan berupa perundang-undangan. Peran serta masyarakat dalam pendidikan bertujuan untuk menciptakan efektivitas dan efisiensi dalam pemanfaatan seluruh sumberdaya dalam mendukung tumbuh kembang anak didik (Miarso, 2007). Kegiatan pendampingan anak di masa transisi new normal juga pernah dilakukan di tempat lain berupa pendampingan dalam belajar dan bermain (Taufik Ridwan dkk., 2021; Citraningrum, 2020) serta pemahaman pentingnya menjaga kesehatan guna terhindar dari infeksi virus corona (Rahmi dkk., 2021; Annisa Yuliazizah, 2020). Dukungan ini salah satunya dapat dilakukan dalam bentuk pengabdian kepada masyarakat. Kegiatan serupa terkait pendampingan anak terutama dalam tranfer pengetahuan terkait kesehatan telah banyak dilakukan, seperti pada anak pra sekolah (Rohita, 2020), melalui senam aerobik (Dwijayanti dkk., 2021), melalui audiovisual (Wardhani, Susilorini dkk., 2020), di tempat les (Lestari, 2021), dan pada balita dan Ibu hamil (Tulak \& Yuhanah, 2020).

Atas dasar pemikiran tersebut maka kami melakukan pengabdian kepada masyarakat dengan mitra PAUD/TK Amalianur, dusun Sidodadi, desa Pematang Seleng, kecamatan Bilah Hulu, kabupaten Labuhanbatu, Sumatera Utara. Pengabdian kepada masyarakat ini dilakukan bertujuan untuk mengurangi kejenuhan yang dialami anak didik akibat lebih banyak belajar dari rumah selama masa transisi new norma dengan menciptakan keceriaan dalam belajar dan bermain yang diselingi dengan bernyanyi. Selain itu juga untuk menambah wawasan pengetahuan bagaimana sikap hidup sehat dengan menjalankan protokol kesehatan (Prokes) selama masa transisi new normal, serta tetap membangun spritual keimanan anak didik melalui hapalan doa-doa singkat Islami.

\section{Metode}

Pelaksanaan pengabdian ini menggunakan 2 metode, yaitu metode ceramah dan metode praktek. Dalam sesi ceramah disampaikan penjelasan mengenai bagaimana sikap hidup sehat di masa transisi new normal. Selanjutnya dalam sesi praktek, dipraktekkan secara langsung bagaimana mencuci tangan yang baik. Diantara kedua sesi diselingi dengan bernyanyi ceria, menghapalkan doa-doa singkat Islami dan huruf Hijaiyah dan kegiatan mewarnai. Adapun mitra pendukung dalam pengabdian ini adalah guru-guru PAUD/TK Amalianur Amalianur, dusun Sidodadi, Desa Pematang Seleng, Kecamatan Bilah Hulu, Kabupaten Labuhanbatu, Sumatera Utara Kegiatan pengabdian ini dilakukan mengikuti 3 alur pelaksanaan kegiatan yaitu Tahap Persiapan, Tahap Pelaksanaan, dan Tahap Evaluasi sebagaimana ditunjukkan pada Gambar 1. 


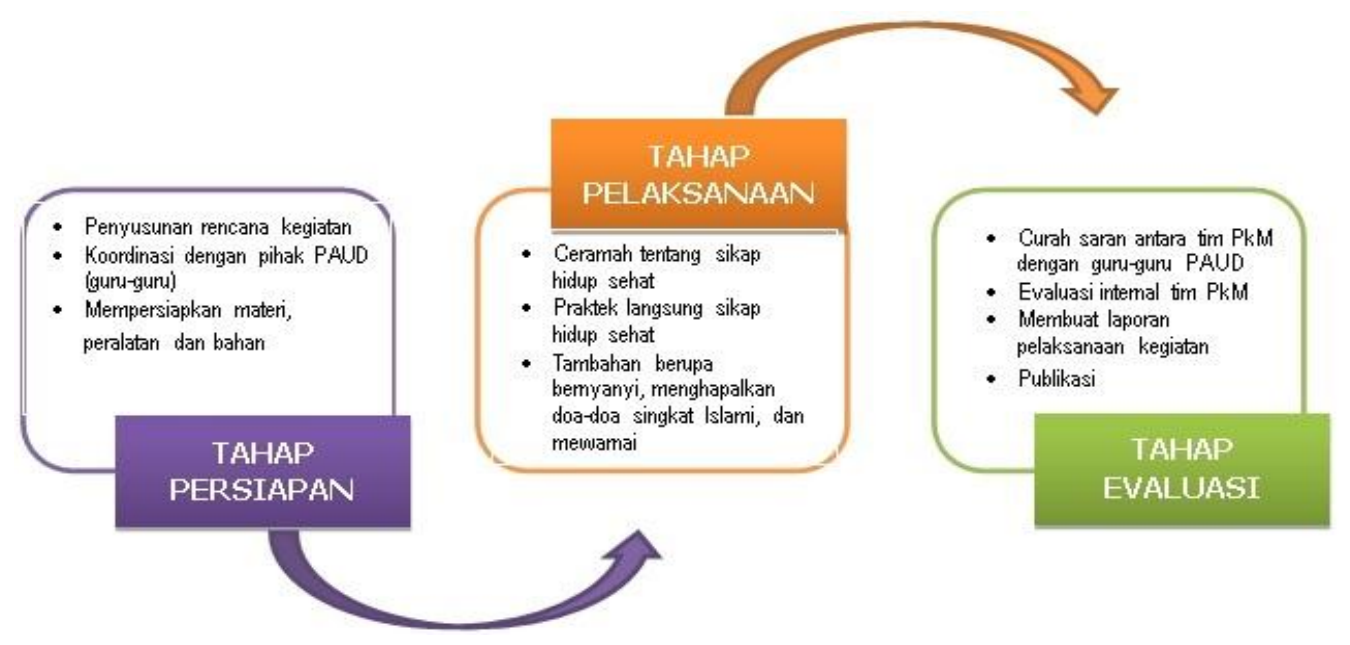

Gambar 1. Alur Pelaksanaan Kegiatan

\subsection{Tahap Persiapan}

Tahap persiapan diawali dengan audiensi dengan Bapak Kades Pematang Seleng untuk menyampaikan rencana pelaksanaan pengabdian masyarakat ini, dilanjutkan dengan koordinasi dengan Kepsek dan dewan guru PAUD/TK Amalianur. Hasil koordinasi disepakati beberapa hal penting yaitu tanggal/waktu/tempat pelaksanaan kegiatan, jumlah peserta didik yang akan menjadi peserta, rancangan rundown kegiatan, peralatan, bahan dan materi ceramah yang akan disampaikan. Persiapan internal tim PkM meliputi pembagian tugas masing-masing anggota tim, persiapan materi, bahan, dan peralatan.

\subsection{Tahap Pelaksanaan}

Tahap pelaksanaan PkM ini dimulai dengan penyampaian ceramah dengan materi "Sikap Hidup Sehat Selama Masa Transisi New Normal". Ceramah diselingi dengan bernyanyi dan bertepuk tangan. Dilanjutkan dengan kegiatan menghapalkan kembali kepada anak didik doa-doa singkat Islami dan huruf Hijaiyah. Agar tetap kreatif, tim PkM juga menyelenggarakan kegiatan lomba mewarnai dengan memberikan hadiah bagi hasil mewarnai yang terbaik menurut panitia tim PkM. Pada akhir pelaksanaan pengabdian ini, tim PkM mempraktekkan secara langsung cara mencuci tangan yang baik dalam rangka bagian dari protokol kesehatan.

\subsection{Tahap Evaluasi}

Tahap evaluasi dilakukan dengan diskusi dan curah saran antara tim PkM dengan guru-guru PAUD/TK Amalianur yang ikut serta. Evaluasi ditujukan untuk menguatkan komitmen dan tanggungjawab bersama dalam mendukung anak didik menjalani masa transisi new normal dengan ceria dan sehat. Selanjutnya tim PkM melakukan evaluasi internal pelaksaan pengabdian, membuat laporan tertulis, dan melakukan publikasi kegiatan di media massa online. 


\section{Hasil dan Pembahasan}

Kegiatan pengabdian kepada masyarakat ini dilakukan di PAUD/TK Amalianur, dusun Sidodadi, desa Pematang Seleng, kecamatan Bilah Hulu, kabupaten Labuhanbatu, Sumatera Utara, pada Kamis, 17 September 2020, dimulai pukul 08.00 WIB. Tahap persiapan diawali dengan beberapa hari sebelumnya telah melakukan audiensi dengan kades Pematang Seleng untuk menyampaikan rencana pelaksanaan pengabdian masyarakat ini atas persetujuan bapak Kades, tim PkM melanjutkan koordinasi dengan Kepsek PAUD/TK Amalianur. Selanjutnya tim PkM melakukan audiensi yang dilanjutan dengan koordinasi dengan Kepsek dan guruguru PAUD/TK Amalianur. Hasil koordinasi disepakati beberapa hal penting yaitu tanggal/waktu/tempat pelaksanaan kegiatan, jumlah peserta didik yang akan menjadi peserta, rancangan rundown kegiatan, peralatan, bahan dan materi ceramah yang akan disampaikan. Persiapan internal tim PkM meliputi pembagian tugas masing-masing anggota tim, persiapan materi, bahan, dan peralatan. Agar pelaksanaan kegiatan PkM ini nantinya berjalan lancar dan tertib, maka tim juga melakukan gladi resik singkat dengan menetapkan durasi untuk tiap sesi kegiatan. Dengan adanya gladi resik singkat ini diharapkan kesalahan bisa diminimalisasi dan waktu bisa dimanfaatkan secara baik.

Pelaksanaan PkM ini telah disepakati akan dilakukan di halaman TK/PAUD Amalianur. Hal ini didasarkan pertimbangan untuk menghindari terjadinya kepadatan individu/kerumuman apabila kegiatan PkM ini dilakukan di dalam ruang kelas. Untuk itu, pagi-pagi kegiatan tim $\mathrm{PkM}$ dan dengan guru-guru bersama-sama menata kursi dan meja di halaman TK/PAUD Amalianur (Gambar 2). Kegiatan ini diikuti oleh peserta didik sejumlah 40 anak, serta dihadiri oleh 6 orang guru PAUD/ TK Amalianur Setiap anak didik menempati kursi masing-masing dengan pengaturan jarak.

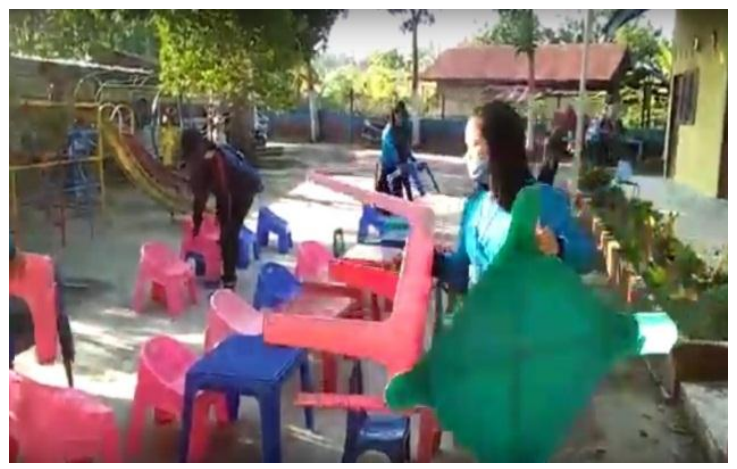

Gambar 2. Proses persiapan kegiatan

Tahap pertama pelaksanaan PkM ini berupa penyampaian ceramah dengan materi "Sikap Hidup Sehat Selama Masa Transisi New Normal". Isi materi ceramah diantara alasan mengapa harus belajar dari rumah sebagai antisipasi menghempang penyebaran virus Covid-19, bagaimana mengatur jam belajar yang baik di rumah, dan bagaimana mematuhi Prokes (memakai masker, rajin cuci tangan, dan mengatur jarak). Ceramah disampaikan dengan bahasa yang ringan dan ceria sehingga isi ceramah lebih mudah dimengerti oleh anak-anak didik 
PAUD/TK. Untuk menciptakan suasana ceria, ceramah diselingi dengan bernyanyi dan bertepuk tangan, yang dapat disajikan pada Gambar 3.

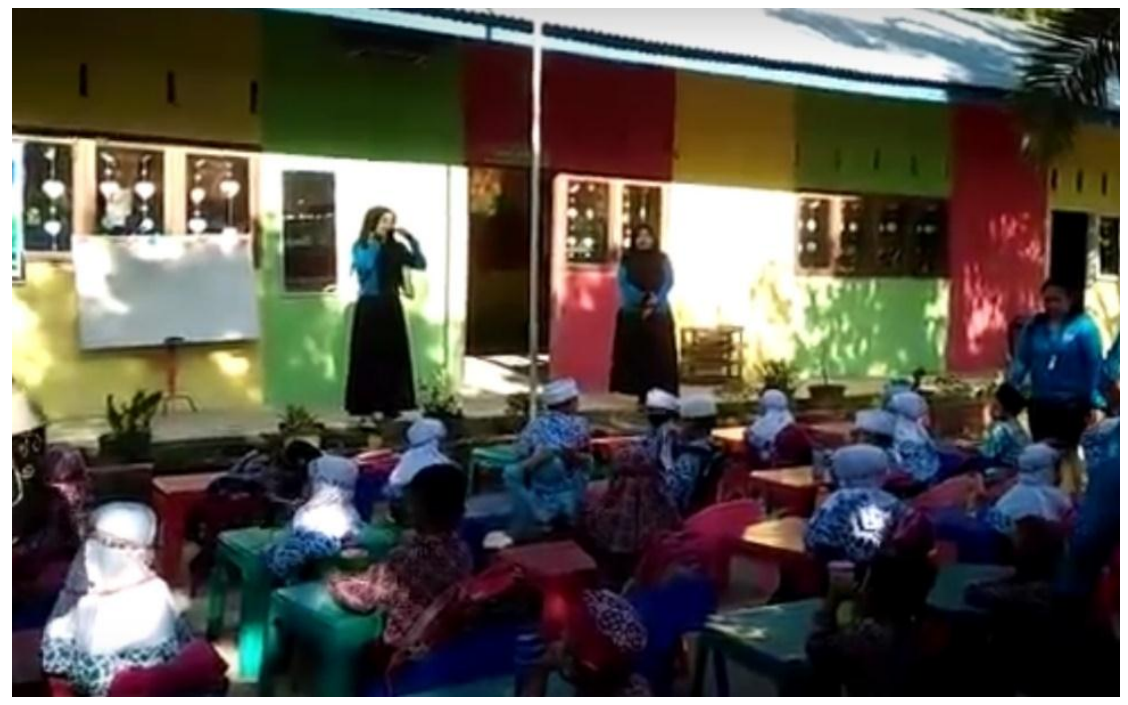

Gambar 3. Ceramah "Sikap Hidup Sehat Selama Masa Transisi New Normal”

Selanjutnya, tim PkM menghapalkan kembali kepada anak didik doa-doa singkat Islami dan huruf Hijaiyah Tujuannya adalah agar anak didik PAUD/TK Amalianur selalu ingat berdoa dan hapalan huruf-huruf Hijaiyah agar tidak lupa dan semakin mahir (Gambar 4). Agar tetap kreatif, tim PkM juga menyelenggarakan kegiatan mewarnai. Kegiatan ini diperlombakan dengan memberikan hadiah bagi hasil mewarnai yang terbaik menurut panitia tim PkM seperti dapat ditunjukkan pada Gambar 5.

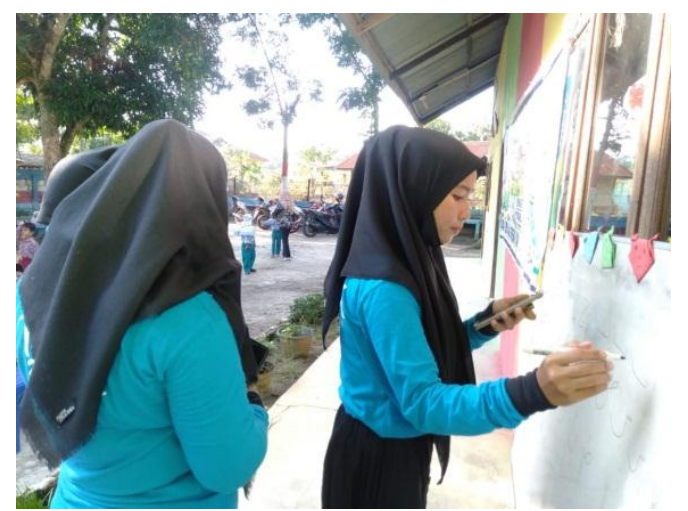

Gambar 4. Mengajarkan kembali huruf Hijaiyah 


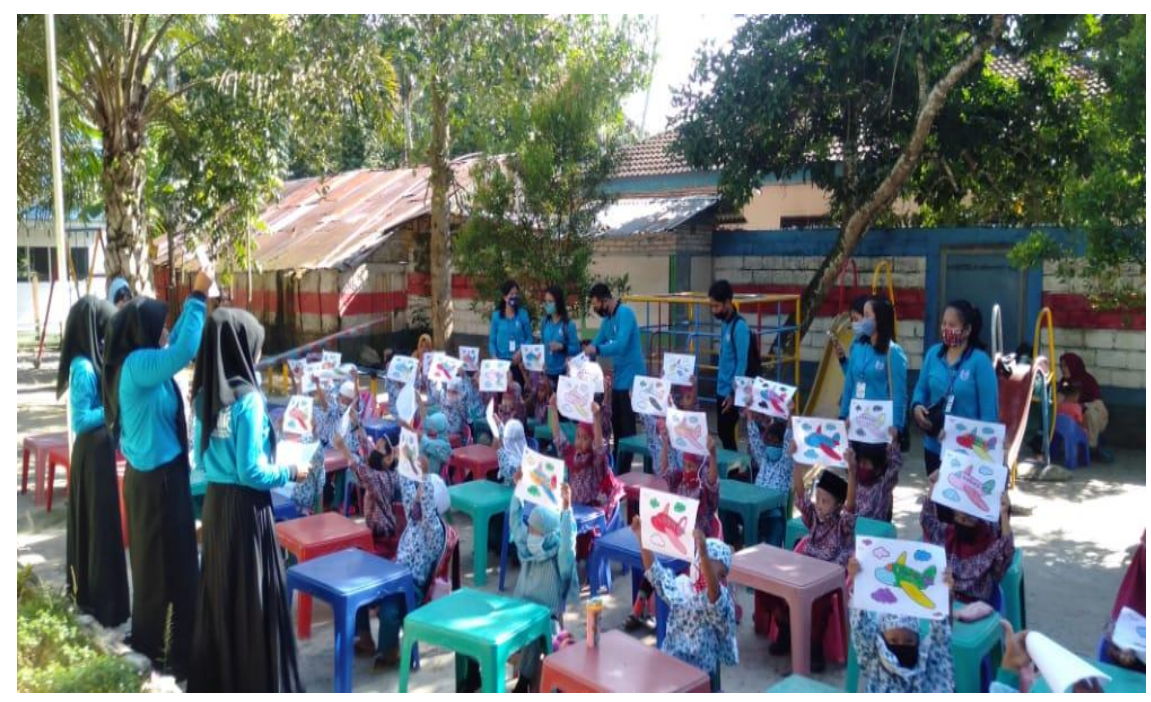

Gambar 5. Kegiatan mewarnai

Pada akhir pelaksanaan pengabdian ini, tim PkM mempraktekkan secara langsung cara mencuci tangan yang baik dalam rangka bagian dari Prokes (Protokol Kesehatan). Beberapa anak didik diminta untuk mengikuti praktek ini, dan mereka dapat melakukannya dengan baik, nampak pada Gambar 6.

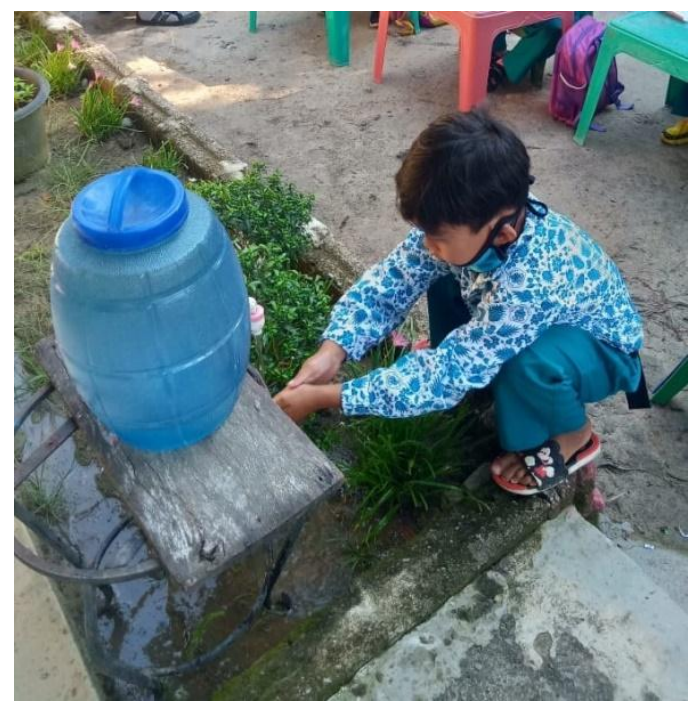

Gambar 6. Praktek Cuci Tangan

Berdasarkan hasil kegiatan yang telah dilakukan maka tujuan dari pendampingan anak ini telah tercapai dengan baik. Bila dibandingkan dengan kegiatan serupa, maka keutamaan dari pengabdian ini yang belum ada dalam pendampingan anak lainya adalah bahwa dalam pengabdian ini telah dimasukkan unsur membangun spritual keimanan anak didik melalui hapalan doa-doa singkat Islami dan mengajarkan kembali huruf-huruf Hijaiyah. 


\section{Kesimpulan}

Anak didik adalah kelompok rentan yang dapat mengalami gangguan kesehatan mental selama diberlakukannya sistem belajar dari rumah. Gangguan itu misalnya timbulnya rasa jenuh, tertekan dengan tugas sekolah (PR) yang menumpuk, ketersendirian di rumah dan sebagainya. Untuk itu, pendampingan belajar sambil bermain merupakan salah satu upaya untuk mengurangi dampak tersebut. Temuan yang muncul dari pelaksanaan pendampingan terhadap anak ini adalah terciptanya suasana baru dan keceriaan dalam belajar dan bermain, yang diharapkan dapat mengurangi kejenuhan yang dialami anak didik akibat telah lama terus-menerus belajar dari rumah. Selain itu, pendampingan ini juga memberikan tambahan wawasan pengetahuan bagaimana sikap hidup sehat (Prokes) selama masa transisi new normal, serta tetap membangun spritual keimanan anak didik melalui hapalan doa-doa singkat Islami dan ajaran huruf-huruf Hijaiyah. Keterbatasan yang dirasakan adalah kegiatan pengabdian ini bersifat insidential dan waktunya terbatas hanya 2 jam. Diharapkan kegiatan ini membawa manfaat bagi mitra dan dapat kami dilakukan di satuan pendidikan lainnya.

\section{Acknowledgement}

Ucapan terimakasih disampaikan kepada Bapak Sumiren selaku Kades Pematang Seleng, Kecamatan Bilah Hulu, Kabupaten Labuhanbatu, kepada mitra PkM yaitu Ibu Amin selaku Kepsek dan Dewan Guru PAUD/TK Amalianur, yang telah memberikan kesempatan kepada kami untuk melakukan kegiatan pengabdian pada masyarakat ini, serta kepada seluruh pihak yang turut serta mendukung kegiatan ini

\section{Daftar Pustaka}

Agustina, P., Bahri, S., \& Bakar, A. (2019). Analisis faktor penyebab terjadinya kejenuhan belajar pada siswa dan usaha guru BK untuk mengatasinya. Jurnal Ilmiah Mahasiswa Bimbingan Dan Konseling, 4(1).

Annisa Yuliazizah, C. A. Y. (2020). PENDAMPINGAN PENDIDIKAN NON FORMAL DI PERUMNAS WINONG PADA MASA PANDEMI COVID-19. UNNES.

Arifa, F. N. (2020). Tantangan Pelaksanaan Kebijakan Belajar Dari Rumah Dalam Masa Darurat Covid-19. Info Singkat;Kajian Singkat Terhadap Isu Aktual Dan Strategis, $\mathrm{XII}(7 / \mathrm{I})$.

Citraningrum, D. M. (2020). PEMANFAATAN PERMAINAN TRADISIONAL PADA MASA PANDEMI Dina. Humaniora Dan Era Disrupsi : E-Prosiding Seminar Nasional Pekan Chairil Anwar, 1(1).

Dwijayanti, K., Ferbrianti, R., \& Pembangunan, U. T. (2021). Menjaga Daya Tahan Tubuh di Masa Pandemi Covid-19 Dengan Senam Aerobik. BERNAS: Jurnal Pengabdian Kepada Masyarakat, 2(1). 
Latifah, U. (2020). Kebijakan Penyelenggaraan Pendidikan Di Masa Pandemi Covid 19 Dan Relevansinya Dengan Pola Asuh Orang Tua Menurut Zakiah Daradjat. Journal of Chemical Information and Modeling.

Lestari, N. D. (2021). Sosialisasi Bahaya Covid-19 dan Protokol Kesehatan Kepada Anak-Anak di Tempat Les Desa Sidorahayu. Humanism: Jurnal Pengabdian Masyarakat, 2(1). https://doi.org/10.30651/hm.v2i1.6749

Maujud, F. (2017). Peran Partisipasi Masyarakat dalam Meningkatkan Mutu Pendidikan Madrasah (Studi Kasus di Madrasah Ibtidaiyah Islahul Muta'allim Pagutan Kota Mataram). PALAPA, 5(2). https://doi.org/10.36088/palapa.v5i2.48

Miarso, Y. (2007). Menyemai Benih Teknologi Pendidikan. Computer.

Ningsih, L. K. (2020). Kejenuhan belajar masa pandemi covid-19 siswa smta di Kedungwungu Indramayu. Malaysian Palm Oil Council (MPOC), 21(1).

Rahmi, R., Pariyanto, P., \& Nopriyeni, N. (2021). Pendampingan Kegiatan Terhadap anak Hinterland Dalam Menghadapi New Normal di Masa Covid-19. Surya Abdimas, 5(1). https://doi.org/10.37729/abdimas.v5i1.884

Robiatul Adawiyah, R. A. (2013). Kecerdasan Emosional, Dukungan Sosial dan Kecenderungan Burnout. Persona:Jurnal Psikologi Indonesia, 2(2). https://doi.org/10.30996/persona.v2i2.97

Rohita, R. (2020). Pengenalan Covid-19 pada Anak Usia Prasekolah: Analisis pada Pelaksanaan Peran Orangtua di Rumah. Jurnal Obsesi : Jurnal Pendidikan Anak Usia Dini, 5(1). https://doi.org/10.31004/obsesi.v5i1.528

Sama, Bahri, S., \& Budiyono, F. (2020). Sinergitas Guru dan Orang Tua dalam Pembelajaran Daring Pada Masa Covid-19 di Kecamatan Kalianget. In "Pendidikan di Masa Pandemi: Menelaah dari Daerah."

Samsiah, S., Ibrahim, M. M., \& Musdalifah, M. (2018). Partisipasi Masyarakat dalam Meningkatkan Mutu Pendidikan di Madrasah Ibtidaiyah Maroanging Kabupaten Bulukumba. El-Idare: Jurnal Manajemen Pendidikan Islam, 4(2).

Taufik Ridwan, Suhandi, Karlina, Fiki Amali, \& Delin Apriyani. (2021). Pendampingan Dinamika Belajar Masa Pandemi COVID-19 Di Kelurahan Tukmudal Sumber Cirebon. Jurnal Indonesia Sosial Sains, 2(1). https://doi.org/10.36418/jiss.v2i1.118

Tulak, G. T., \& Yuhanah. (2020). Edukasi Penggunaan Masker Pada Kelompok Masyarakat Beresiko Sebagai Bentuk Pencegahan Penyebaran Covid-19. Jurnal Ilmiah Pengbdian Kepada Masyarakat, 4(2).

Wardhani, D. K., Susilorini, M. R., Angghita, L. J., \& Ismail, A. (2020). Edukasi Pencegahan Penularan COVID-19 Pada Anak Usia Dini Melalui Media Pembelajaran Audio Visual. Jurnal Abdidas, 1(3). https://doi.org/10.31004/abdidas.v1i3.33

Yulianingsih, W., Suhanadji, S., Nugroho, R., \& Mustakim, M. (2020). Keterlibatan Orangtua dalam Pendampingan Belajar Anak selama Masa Pandemi Covid-19. Jurnal Obsesi: Jurnal Pendidikan Anak Usia Dini, 5(2). https://doi.org/10.31004/obsesi.v5i2.740 